\title{
Complementary use of in sacco and in vitro studies to investigate ruminal forage degradation in relation to gas production
}

\author{
A Smacchia, R Figallo, A Pidello \\ Laboratorio de Quimica Biologica, Facultad de Cs Veterinarias, Universidad Nacional \\ de Rosario, O Lagos y Ruta 33 (2170) Casilda, Argentina
}

\begin{abstract}
Alfalfa hay (DM) degradation, was determined in sacco in three sheep for two periods and the results were adjusted according to Ørskov and Mc Donald (1979, J Agric Sci Camb, 92, 499503). Compound samples of residues were taken at $0,4,12,24$ and $48 \mathrm{~h}$. Five subsamples of each one $(0.3 \mathrm{~g})$ were incubated in vitro under anaerobic conditions at $39^{\circ} \mathrm{C}$, for 24 h. The batch system used, consisted in $50 \mathrm{ml}$ glass bottles that contained $30 \mathrm{ml}$ filtered ruminal content $\left(0.2 \mathrm{~cm}^{2}\right.$ mesh), connected to a $20 \mathrm{ml}$ glass syringe. In control systems only ruminal fluid was incubated. Ruminal content was taken out of 3 fistulated sheep before morning feeding.

Gas production was registered every hour during the first $12 \mathrm{~h}$ and at $24 \mathrm{~h}$. The syringes were emptied at 7 and $12 \mathrm{~h}$. Incubation was interrupted at $24 \mathrm{~h}$ and gas composition $\left(\mathrm{CO}_{2}\right.$ and $\mathrm{CH}_{4}$ ) was determined on a gas chromatograph. The $\mathrm{pH}$ and oxidation reduction potential (ORP ; mV) in ruminal fluid were determined at the end of incubations.
\end{abstract}

In vitro gas production in vitro showed a negative relation with the degraded $D M$ of incubated samples $(r=-0.92 ; P \leq 0.01)$ and was higher in T0 and T4 $(51 \mathrm{ml} \pm 2)$ than in $\mathrm{T} 12, \mathrm{~T} 24$ and T48 $(28 \mathrm{ml} \pm 1)$. At end of incubation, the $\mathrm{pH}$ showed a positive relation with a degraded $D M(r=0.95 ; P \leq 0.01)$ what confirms the higher fermentatibility of TO and T4 remains. The final ORP showed a negative relation with degraded $D M(r=-0.64 ; P \leq 0.01)$; this result shows that the most resistant material to degradation produced more reducing conditions when incubated in in vitro system.

The results show clearly that the higher gas production and the changes at physical and chemical level can be associated with the fraction of studied material that degrade at the first $4 \mathrm{~h}$ in ruminal environment and suggest the interest to investigate the role of the most resistant components (phenolic type, for example) in $\mathrm{pH}$-ORP changes.

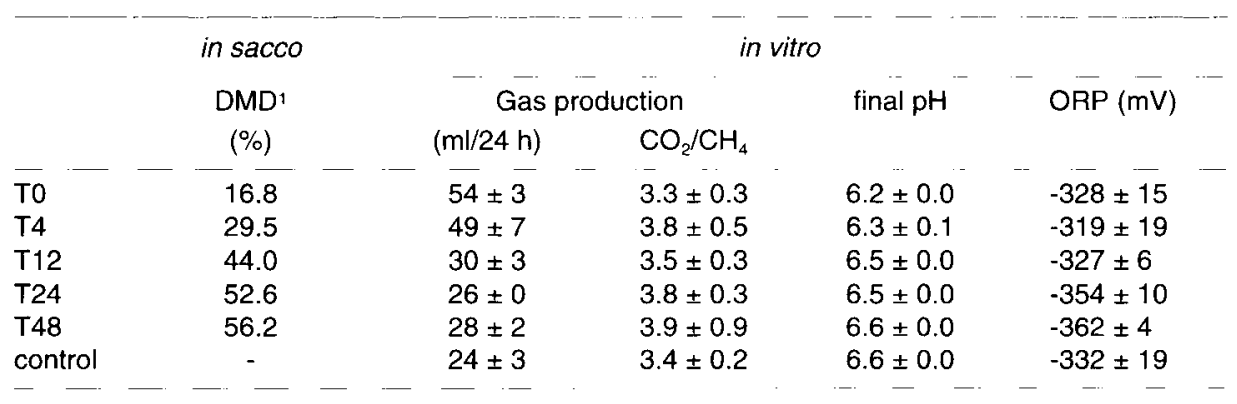

1 Dry Matter Degradation, estimated from $a+b\left(1-e^{-c t}\right), \varnothing r s k o v$ and Mc Donald, 1979. 